\title{
Role of C3 plant species on carbon dioxide and methane emissions in Mediterranean constructed wetland
}

\author{
Carmelo Maucieri, ${ }^{1}$ Maurizio Borin, ${ }^{1}$ Antonio C. Barbera ${ }^{2}$ \\ ${ }^{1}$ Department of Agronomy, Food, Natural Resources, Animals and Environment, University of \\ Padua, Legnaro (PD); ${ }^{2}$ Department of Agriculture and Food Science, University of Catania, Italy
}

\begin{abstract}
C3 plant species are widely used to vegetate constructed wetlands (CW), but so far no information is available on their effect on CW $\mathrm{CO}_{2(\mathrm{eq})}$ balance in the Mediterranean climate. The aim of this research was to study carbon dioxide $\left(\mathrm{CO}_{2}\right)$ and methane $\left(\mathrm{CH}_{4}\right)$ emissions and $\mathrm{CO}_{2(\mathrm{eq})}$ budgets of $\mathrm{CW}$ horizontal sub-surface flow pilot-plant beds vegetated with Arundo donax L. and Phragmites australis (Cav.) Trin. ex Steud. compared with an unvegetated bed in Sicily. The highest total plant biomass production was measured in the bed vegetated with $A$. donax $\left(17.0 \mathrm{~kg} \mathrm{~m}^{-2}\right)$, whereas $P$. australis produced $7.6 \mathrm{~kg} \mathrm{~m}^{-2} . \mathrm{CO}_{2}$ and $\mathrm{CH}_{4}$ emissions and showed significant correlation with average air temperature and solar radiation for each bed. The $\mathrm{CO}_{2}$ emission values ranged from $0.8 \pm 0.1 \mathrm{~g} \mathrm{~m}^{-2} \mathrm{~d}^{-1}$, for the unvegetated bed in April, to $24.9 \pm 0.6 \mathrm{~g} \mathrm{~m}^{-2} \mathrm{~d}^{-1}$ for the bed with $P$. australis in August. The average $\mathrm{CO}_{2}$ emissions of the whole monitored period were $15.5 \pm 7.2,15.1 \pm 7.1$ and $3.6 \pm 2.4 \mathrm{~g} \mathrm{~m}^{-2} \mathrm{~d}^{-1}$ for A. donax, P. australis and unvegetated beds respectively. The $\mathrm{CH}_{4}$ fluxes differed significantly over the monitored seasons, with the highest median value being measured during spring $\left(0.963 \mathrm{~g} \mathrm{~m}^{-2} \mathrm{~d}^{-1}\right)$. No statistical differences were found for $\mathrm{CH}_{4}$ flux
\end{abstract}

Correspondence: Carmelo Maucieri, Department of Agronomy, Food, Natural Resources, Animals and Environment (DAFNAE), University of Padua, Agripolis Campus, viale dell'Università 16, 35020 Legnaro (PD), Italy.

E-mail: carmelo.maucieri@hotmail.it

Key words: Arundo donax L., Phragmites australis (Cav.) Trin. ex Steud., methane, carbon dioxide, $\mathrm{CO}_{2(\mathrm{eq})}$ balance, biomass production, horizontal subsurface flow constructed wetland.

Acknowledgments: the research was supported by Progetto AGER, grant no. 2010-2220 on the basis of the research agreement with the Department of Agronomy, Food, Natural Resources, Animals and Environment (University of Padua) and the Department of Agriculture and Food Science (University of Catania). The authors thank Prof. Salvatore Barbagallo, Prof. Giuseppe L. Cirelli and Prof. Attilio Toscano for making the constructed wetland pilot plant available.

Received for publication: 24 March 2014.

Revision received: 17 June 2014.

Accepted for publication: 24 June 2014.

(C) Copyright C. Maucieri et al., 2014

Licensee PAGEPress, Italy

Italian Journal of Agronomy 2014; 9:601

doi:10.4081/ija.2014.601

This article is distributed under the terms of the Creative Commons Attribution Noncommercial License (by-nc 3.0) which permits any noncommercial use, distribution, and reproduction in any medium, provided the original author(s) and source are credited. among the studied beds. Cumulative estimated $\mathrm{CH}_{4}$ emissions during the study period (from April to December) were 159.5, 134.1 and 114.7 $\mathrm{g} \mathrm{m}^{-2}$ for $A$. donax, $P$. australis and unvegetated beds respectively. $\mathrm{CO}_{2(\mathrm{eq})}$ balance showed that the two vegetated beds act as $\mathrm{CO}_{2(\mathrm{eq})}$ sinks, while the unvegetated bed, as expected, acts as a $\mathrm{CO}_{2(\mathrm{eq})}$ source. Considering only the above-ground plant biomass in the $\mathrm{CO}_{2(\mathrm{eq})}$ budgets, $P$. australis and A. donax determined uptakes of 1.30 and $8.35 \mathrm{~kg}$ $\mathrm{CO}_{2(\mathrm{eq})} \mathrm{m}^{-2}$ respectively.

\section{Introduction}

C3 plant species are widely used to vegetate constructed wetlands (CWs), which are common natural-like systems (Vymazal, 2010) adopted to treat different wastewaters: landfill leachate (Bulc, 2006), agriculture drainage and animal wastewater (Borin and Tocchetto, 2007; Borin et al., 2013a), textile wastewater (Bulc and Ojstršek, 2008), urban wastewater (Barbera et al., 2009), pesticides (0'Geen et al., 2010). In these systems the organic carbon fraction content in the wastewaters is mainly removed through volatilization, determining a positive flux of greenhouse gases (GHGs), such as carbon dioxide $\left(\mathrm{CO}_{2}\right)$ and methane $\left(\mathrm{CH}_{4}\right)$ into the atmosphere. However, the atmospheric $\mathrm{CO}_{2}$ uptake by plant photosynthesis can balance $\mathrm{CO}_{2(\mathrm{eq})}$ fluxes (Barbera et al., 2014a). In general plants through their root systems (Lai et al., 2011) influence $\mathrm{CO}_{2}$ production (Ström et al., 2005) and $\mathrm{CH}_{4}$ production and consumption (Segers, 1998; Ström et al., 2005; Wang et al., 2008), mainly through roots oxygen (Griess et al., 1990) and exudate release (Brix et al., 2001). In particular, plant species with different physiology and therefore different magnitude of oxygen (Wigand et al., 1997) and exudate release (Ström et al., 2003) can determine a different $\mathrm{CO}_{2}: \mathrm{CH}_{4}$ ratio emission and global warming potential (GWP) given that $\mathrm{CH}_{4}$ has a GWP 25 times higher than $\mathrm{CO}_{2}$ (IPCC, 2007). In the Mediterranean basin, where temperatures in late spring and summer are high, the use of C3 species in CWs could determine a different environmental $\mathrm{C}$ balance compared with the CWs located at higher latitude.

Several studies on GHG emission, at different latitudes, include CW beds vegetated with Phragmites australis, which is the most widely studied C3 species. Only a few studies have been carried out in a Mediterranean environment on GHG emission from pilot-plant CWs (Garcia et al., 2007; Barbera et al., 2014a) or a full-scale CW (Barbera et al., 2014b) vegetated with $P$. australis or C4 plant species. To our knowledge no studies have focused on $\mathrm{GHG}$ emission from CWs vegetated with Arundo donax (C3 species), either in a Mediterranean environment or at other latitudes.

The question if wetlands act as sinks or sources of GHGs has recently gained increasing importance to understand more thoroughly the role of the ecosystem services that they provide (Mitsch et al., 2013) and address their management. Since vegetation is the key component of CWs, its role needs to be definitely better understood. 
In this contest the aim of this research was to compare $\mathrm{CO}_{2}$ and $\mathrm{CH}_{4}$ emissions and $\mathrm{CO}_{2(\mathrm{eq})}$ budgets of $\mathrm{CW}$ horizontal sub-surface flow (HSSF) pilot-plant beds unvegetated or vegetated with A. donax L. and P. australis (Cav.) Trin. ex Steud.

\section{Materials and methods}

\section{Study sites}

The research was conducted from April $1^{\text {st }}$ to December $20^{\text {th }} 2012$ in a pilot plant located in San Michele di Ganzaria (Eastern Sicily - lat. $37^{\circ} 30^{\prime} \mathrm{N}$, long. $14^{\circ} 25^{\prime} \mathrm{E}$, alt. $370 \mathrm{~m}$ asl). The area has a typical Mediterranean climate (Köppen climate classification) with medium rainfall (approximately $500 \mathrm{~mm} \mathrm{y}^{-1}$ ) mainly in winter. The pilot plant consisted of three parallel HSSF beds, two vegetated with $P$. australis (Cav.) Trin. ex Steud. (common reed) and A. donax L. (giant reed) and one unvegetated control bed. Each bed was rectangular in shape with a surface area of $4.5 \mathrm{~m}^{2}(1.5 \times 3.0 \mathrm{~m})$ and was built of concrete, partially buried, and lined with an impermeable membrane. The beds were filled to an average depth of $0.6 \mathrm{~m}$, with $10-15 \mathrm{~mm}$ volcanic gravel; during the monitoring period, water depth was about $0.55 \mathrm{~m}$. System details are available in Toscano et al. (2009). Wastewater inflow was $40 \mathrm{~L} \mathrm{~h}^{-1}$. Beds were planted in December 2011 at a density of 5.5 plants $\mathrm{m}^{-2}$.

\section{Studied C3 species}

P. australis is the most frequently used macrophyte to vegetate CWs. It is a tall perennial grass of the Poaceae family found in natural wetlands across temperate and tropical regions of the world. It commonly forms extensive stands (known as reed beds) and is capable of reproduction by seed, but primarily asexually multiplication via rhizomes. $P$. australis is a C3 plant species characterised by aerating tissues (aerenchyma channels and pith cavities) which play a crucial role in this species and generally in aquatic plants by providing oxygen to the submerged organs and often to the rhizosphere (Engloner, 2009).

A. donax is a tall perennial herbaceous plant of the same family occurring in grasslands and wetlands over a wide range of climatic habitats. It is classified as an emergent aquatic plant (Cook, 1990). Like $P$. australis, it is a C3 species, with an unusually high photosynthetic capacity (Rossa et al., 1998) and productivity similar to that of C4 species (Christou et al., 2001; Borin et al., 2013b).

\section{Meteorological variables}

A CR510 automatic weather station (Campbell Scientific, Logan, UT, USA) was installed close to the experimental plant to measure rainfall, air temperature, wind speed and global radiation. Evapotranspiration rates were estimated using a water balance method, measuring for each bed the influent wastewater flow rate, the water increase due to precipitation and the discharged wastewater volume.

\section{Gas sampling and analyses}

$\mathrm{CO}_{2}$ and $\mathrm{CH}_{4}$ sampling and analysis were performed from April $1^{\text {st }}$ (vegetative regrowth) to December $20^{\text {th }} 2012$ (end of vegetative cycle). The gas samplers did not cover growing plants.

$\mathrm{CO}_{2}$ emissions were estimated in situ using the static-stationary chamber technique. The cylindrical chambers, of PVC, were $35 \mathrm{~cm}$ high and $12.5 \mathrm{~cm}$ wide. The bottom part $(20 \mathrm{~cm})$ was permanently inserted in the gravel substrate and the chamber was sealed with a lid in which the $\mathrm{CO}_{2}$ emitted from the bed was absorbed in a sodium hydroxide
$(\mathrm{NaOH})$ solution trap following modifications reported in Barbera et al. (2014b) to reduce experimental error (Jensen et al., 1996). The $\mathrm{CO}_{2}$ traps, two in each bed, were placed in the inner part of the beds to reduce the border effect. They were replaced every ten days, therefore the monthly total bed respiration (respiration of bed microbes, roots and rhizomes) was calculated based on a decadal dataset.

$\mathrm{CH}_{4}$ flux was measured using the static non-stationary chamber technique (Barbera et al., 2014a) three times a month in two microsites in order to replicate the measures. The flux cylindrical chamber, $42 \mathrm{~cm}$ high and $20 \mathrm{~cm}$ wide, was inserted into the gravel substrate using a permanent ring inserted into the substrate before the beginning of measurements to prevent soil disturbance in each site. The surface $\mathrm{CH}_{4}$ flux was determined by measuring the temporal change in $\mathrm{CH}_{4}$ concentration inside the chamber using a portable flame ionisation detector (Crowcon Gas-Tec®); Crowcon Detection Instruments Ltd., Abingdon, UK) detecting $\mathrm{CH}_{4}$ concentrations down to parts per million levels.

\section{Biomass sampling and analyses}

In December 2012 above-ground and below-ground biomasses were sampled from three points in the inner part of each bed in order to minimize the border effect. The below-ground biomass was collected at three depths $(0-20,20-40$ and 40-60 cm) and was divided in roots and rhizomes. Biomass sub-samples were homogenized for quality analysis: biomass dry weight was determined using a thermo-ventilated oven at $65^{\circ} \mathrm{C}$ until constant weight was reached. Biomass $\mathrm{C}$ content was determined by CNS Macrovario combustion analyzer (Elementar Analysensysteme GmbH, Hanau, Germany).

\section{Growing season $\mathrm{CO}_{2(\mathrm{eq})}$ balance}

Carbon environmental balance was calculated considering $\mathrm{CO}_{2}$ and $\mathrm{CH}_{4}$ emissions and the storage of fixed carbon in plant biomass in terms of $\mathrm{CO}_{2(\mathrm{eq})}$ using the following formula:

$$
\mathrm{CO}_{2(\mathrm{eq})}=\mathrm{CO}_{2}+\left(\mathrm{CH}_{4} * 25\right)+\mathrm{C}_{\text {biomass }} *(44 / 12)
$$

where:

- $\mathrm{CO}_{2}$ and $\mathrm{CH}_{4}$ were the $\mathrm{GHG}$ emissions measured during the growing season;

- the $\mathrm{CH}_{4}$ emission for $\mathrm{CO}_{2(\mathrm{eq})}$ budgets was computed as 25 times $\mathrm{CO}_{2}$ (IPCC, 2007);

- 44 represents the molecular weight of $\mathrm{CO}_{2}$, and 12 is the $\mathrm{C}$ atomic weight.

As indicated by Mander et al. (2008), the above-ground plant biomass respiration was not considered, assuming that respired $\mathrm{C}$ was previously assimilated by plant gross photosynthesis.

\section{Statistical analysis}

The normality of data was tested using the Kolmogorov-Smirnov, Lilliefors, and Shapiro-Wilk tests. $\mathrm{CO}_{2}$ and $\mathrm{CH}_{4}$ emissions from the study sites did not show a normal distribution, so the Kruskal-Wallis non-parametric test was used to check the significance of differences (accepted at the level of $\mathrm{P} \leq 0.05$ ) using a combination of replications in time and space rather than through independent experimental units. Correlations between average air temperature and solar radiation with $\mathrm{CO}_{2}$ and $\mathrm{CH}_{4}$ emissions were evaluated using Spearman Rank correlation. The range distribution of biomass and emission values was expressed in terms of standard deviation. 


\section{Results and discussion}

\section{Environmental parameters}

Meteorological data recorded at the site during the monitoring period (April-December 2012) are reported in Figure 1. Cumulative rainfall was $105.8 \mathrm{~mm}$; the air temperature reached its maximum value on July $13^{\text {th }}$ $\left(43.4^{\circ} \mathrm{C}\right)$ and its minimum value on December $13^{\text {th }}\left(0.2^{\circ} \mathrm{C}\right)$. The highest monthly average solar radiation value $\left(27.6 \mathrm{MJ} \mathrm{m}^{-2} \mathrm{~d}^{-1}\right)$ was recorded in July and the average wind speed was generally below $1 \mathrm{~ms}^{-1}$. The correlation between average air temperature and solar radiation with $\mathrm{CO}_{2}$ and $\mathrm{CH}_{4}$ emissions showed a specific response for each bed (Table 1). $\mathrm{CO}_{2}$ emission was positively correlated with average air temperature in the bed vegetated with $P$. australis $(\mathrm{P}<0.001)$, instead no correlation was found for A. donax. For all beds $\mathrm{CH}_{4}$ emission was positively correlated with solar radiation $(\mathrm{P}<0.001)$, whereas only the unvegetated bed showed a positive correlation between $\mathrm{CH}_{4}$ emission and average air temperature $(\mathrm{P}<0.05)$. These results are undoubtedly interesting, but caution must be used due to the short monitoring period of about nine months and considering that the study was carried out during the first operating year and so the systems did not reach the below-ground biomass turnover with a low amount of sludge accumulated in the beds. Both conditions could determine, in the following years, different emission ratios between the two species and different responses to environmental conditions.

\section{Plants biomass production}

At the end of the vegetative season, A. donax showed the higher total plant biomass yield ( $16.8 \mathrm{~kg} \mathrm{~m}^{-2}$ ), while $P$. australis produced $7.5 \mathrm{~kg} \mathrm{~m}^{-2}$. Considering the plant organs, giant reed has always scored the highest biomass production, namely 1.8, 5.1 and 3.3 times higher than the common reed in terms of biomass of above-ground portion, roots and rhizomes respectively. Roots density declined with depth in the bed vegetated with $A$. donax, whereas for $P$. australis higher density was found in the $20-40 \mathrm{~cm}$ gravel layer. Rhizomes were distributed only in the first $20 \mathrm{~cm}$ of substrate for A. donax and in the $0-40 \mathrm{~cm}$ layer for $P$. australis (Table 2). At the end of the study period, $P$. australis showed a higher above-ground/below-ground ratio (2.7) than A. donax (1.5; Table 2). The reported high above-ground production confirms the high productive potential of the two species cultivated under optimal water and nutritional conditions (Idris et al., 2012a; Borin et al., 2013b).

\section{Greenhouse gases emissions}

The average $\mathrm{CO}_{2}$ emission was significantly lower in spring for all studied $\mathrm{CW}$ beds (Figure $2 \mathrm{~A}$ ) with the lowest monthly $\mathrm{CO}_{2}$ average daily emission recorded in April with 5.2 $\pm 1.6,6.1 \pm 1.0$ and $0.8 \pm 0.1 \mathrm{~g} \mathrm{~m}^{-2} \mathrm{~d}^{-1}$ for common reed, giant reed and unvegetated beds respectively. The highest monthly average daily $\mathrm{CO}_{2}$ emissions were recorded in August for common reed $\left(24.9 \pm 0.6 \mathrm{~g} \mathrm{~m}^{-2} \mathrm{~d}^{-1}\right)$ and in September for giant reed $\left(24.3 \pm 2.7 \mathrm{~g} \mathrm{~m}^{-2} \mathrm{~d}^{-1}\right)$ and the unvegetated bed $\left(6.6 \pm 1.1 \mathrm{~g} \mathrm{~m}^{-2} \mathrm{~d}^{-1}\right)$. With respect to season averages, no significant differences were found in $\mathrm{CO}_{2}$ emission between $A$. donax and $P$. australis beds, instead a significantly lower emission was recorded for the unvegetated bed (Figure $2 B$ ), with a median value 4.3 times lower than the average median value of vegetated beds. Bed respiration did not show any species-specific effect, but there was a significantly higher emission from vegetated beds than the unvegetated one, confirming that the presence of vegetation is very important for the respiration of $\mathrm{CW}$ total ecosystems (Ström et al., 2007). Nevertheless the effect of different species may be present, as suggested by Maltais-Landry et al. (2009) who reported significant differences among HSSF CW mesocosms vegetated with $P$. australis, Phalaris arundinacea and Typha angustifolia.
In our study the average respiration of the bed throughout the entire monitored period was $15.1 \pm 7.1,15.5 \pm 7.2$ and $3.6 \pm 2.4 \mathrm{~g} \mathrm{CO}_{2} \mathrm{~m}^{-2} \mathrm{~d}^{-1}$ for $P$. australis, A. donax and unvegetated beds respectively, in agreement with Barbera et al. (2014b) who reported, in the same area, higher $\mathrm{CO}_{2}$ emissions from vegetated sites than an unvegetated one in a full scale HSSF CW. Even at higher latitudes in Southern Sweden, Ström et al. (2007) reported an average $\mathrm{CO}_{2}$ flux of $25.1 \pm 4.7$ and $4.3 \pm 0.7 \mathrm{~g} \mathrm{~m}^{-2} \mathrm{~d}^{-1}$ from a zone vegetated with $P$. australis and an unvegetated zone respectively in a peat-based $\mathrm{CW}$ site. Søvik et al. (2006) reported an average $\mathrm{CO}_{2}$ emission of $2.5 \pm 0.2$ and $10.6 \pm 0.6 \mathrm{~g} \mathrm{~m}^{-2} \mathrm{~d}^{-1}$ during winter and summer respectively in a comparative study conducted in northern Europe (Estonia, Norway and Poland) on GHG emissions from vegetated HSSF CWs (P. australis, Iris pseudocorus, Typha latifolia, and Scirpus lacustris). Picek et al. (2007) reported $\mathrm{CO}_{2}$ emissions varying between 0.4 and $27.2 \mathrm{~g} \mathrm{~m}^{-2} \mathrm{~d}^{-1}$ during summer and fall in an HSSF CW bed vegetated with $P$. australis that treated combined sewage and stormwater runoff.

In our study common and giant reed showed similar $\mathrm{CO}_{2}$ cumulative emissions, with about 3.98 and $4.08 \mathrm{~kg} \mathrm{~m}^{-2}$ respectively, whereas the
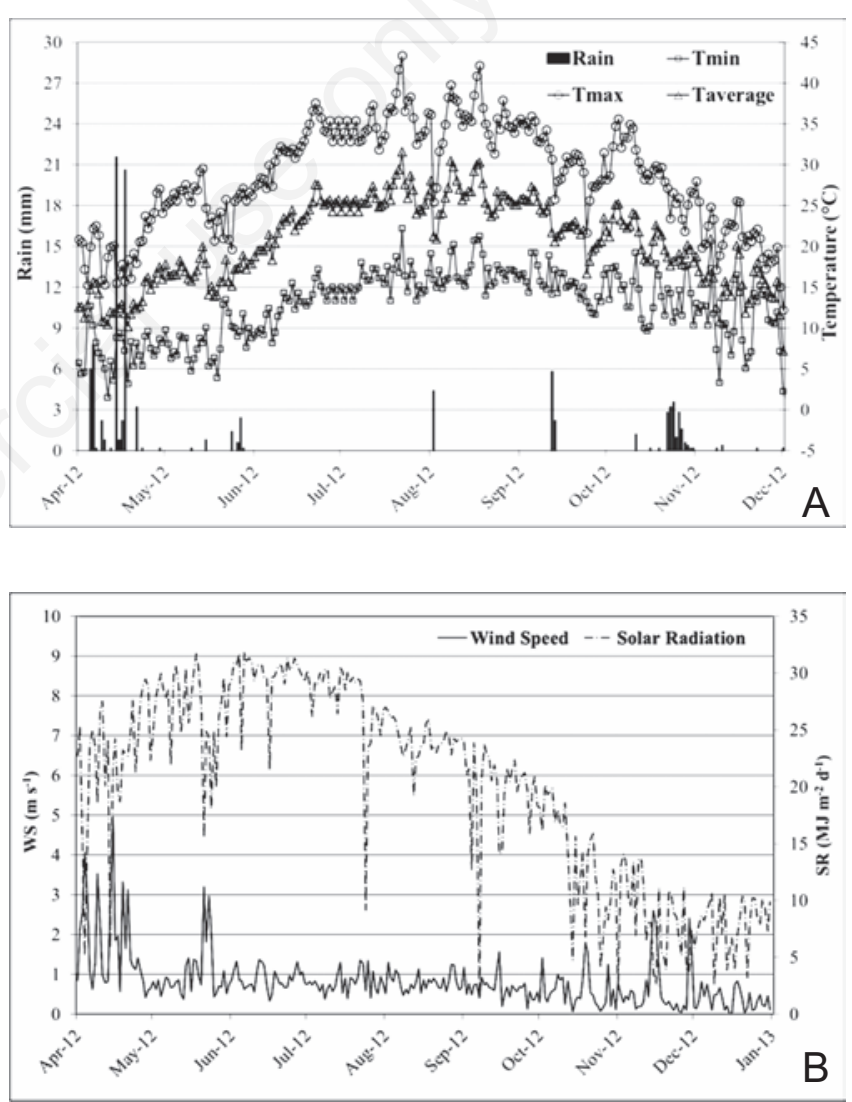

Figure 1. A) and B) Meteorological data recorded in San Michele di Ganzaria during the study period.

Table 1. Correlation of $\mathrm{CO}_{2}$ and $\mathrm{CH}_{4}$ bed emissions with temperature and solar radiation.

\begin{tabular}{lccc} 
Correlation & P. australtis & A. donax & Unvegetated \\
$\mathrm{CO}_{2}$ vs solar radiation & 0.108 n.s. & -0.311 n.s. & $-0.541^{* *}$ \\
$\mathrm{CO}_{2}$ vs average air temperature & $0.789^{* * *}$ & 0.293 n.s. & 0.196 n.s. \\
\hline $\mathrm{CH}_{4}$ Us solar radiation & $0.760^{* * *}$ & $0.818^{* * *}$ & $0.798^{* * *}$ \\
$\mathrm{CH}_{4}$ Us average air temperature & $0.191 \mathrm{n} . \mathrm{s}$. & 0.341 n.s. & $0.477^{*}$ \\
\hline
\end{tabular}

${ }^{*} \mathrm{P}<0.05 ; * * \mathrm{P}<0.01 ; * * * \mathrm{P}<0.001$. n.s., not significant; 
unvegetated bed reported $0.94 \mathrm{~kg} \mathrm{~m}^{-2}$.

The fluxes of $\mathrm{CH}_{4}$ were significantly different among the studied seasons (Figure 3A). The highest median value was measured during spring $\left(0.963 \mathrm{~g} \mathrm{~m}^{-2} \mathrm{~d}^{-1}\right)$, followed by summer $\left(0.399 \mathrm{~g} \mathrm{~m}^{-2} \mathrm{~d}^{-1}\right)$ and fall $\left(0.018 \mathrm{~g} \mathrm{~m}^{-2} \mathrm{~d}^{-1}\right)$. The highest $\mathrm{CH}_{4}$ spring emission was probably due to the plant settlement phase characterised by: i) a fast development of root system resulting in high release of exudates that improved the activity of methanogen microorganisms (Brix et al., 2001; Ström et al., 2003; Saarnio et al., 2004) in vegetated beds. This is supported by the positive correlation between $\mathrm{CH}_{4}$ emissions and solar radiation, which influenced root exudates by photosynthesis activity (Grayston et al. 1997); ii) the incomplete root system development that determined less oxygen presence in the bed and so lower $\mathrm{CH}_{4}$ oxidation rate.
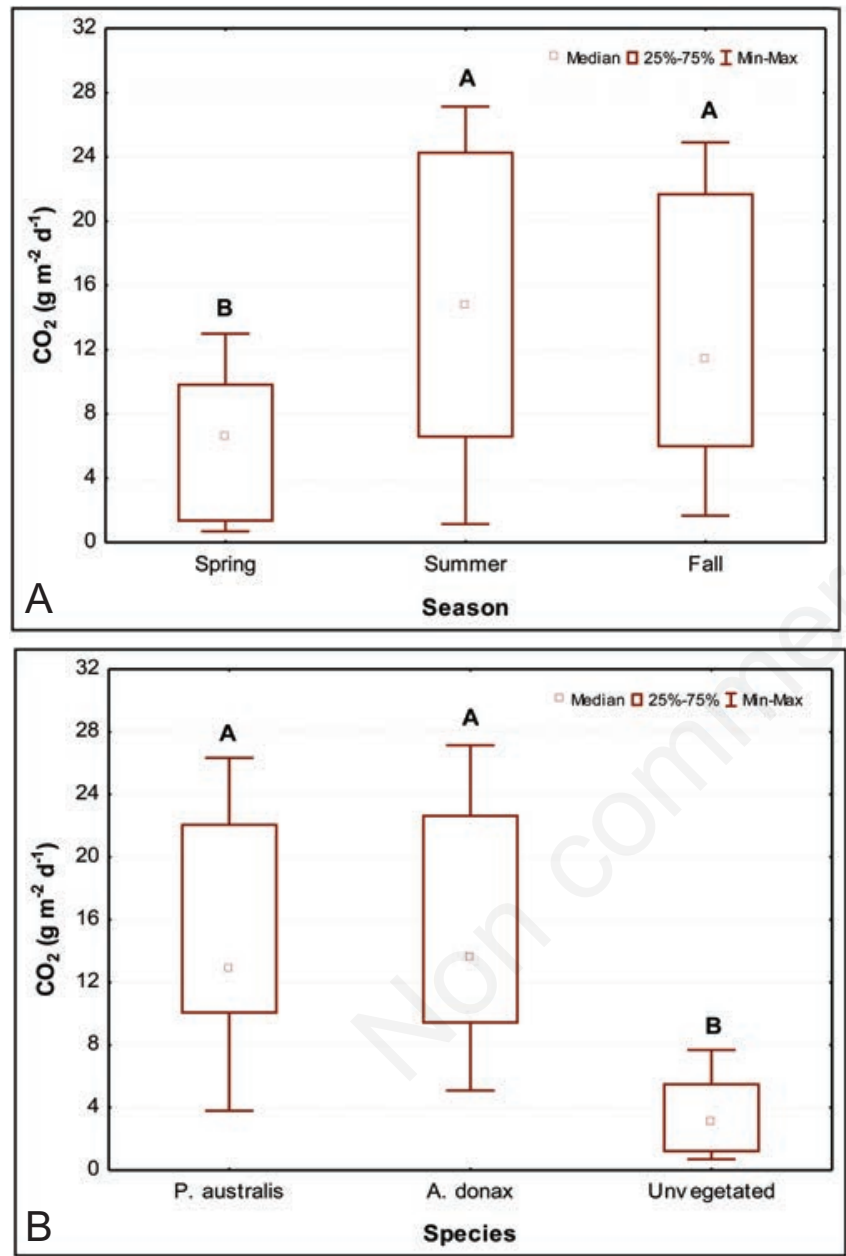

Figure 2. Emission of carbon dioxide beds: A) in different seasons and $B$ ) with different species.
Considering the unvegetated bed, the significant $(\mathrm{P} \leq 0.001)$ positive correlation between $\mathrm{CH}_{4}$ emission and solar radiation can be supported by the indirect effect of the latter on substrate and water temperature. Furthermore only for the unvegetated bed $\mathrm{CH}_{4}$ emissions were also correlated $(\mathrm{P} \leq 0.05)$ with average air temperature, in agreement with Tanner et al. (1997) who found a correlation between air temperature and $\mathrm{CH}_{4}$ emissions, and with Sorrel et al. (1997) who reported significantly lower methanogenesis at $12^{\circ} \mathrm{C}$ than $30^{\circ} \mathrm{C}$. Johansson et al. (2004) studied $\mathrm{CH}_{4}$ emission from ponds where urban wastewater was treated and reported that sediment and water temperatures explained a large proportion of the flux variations (33-43\%).

No statistical differences were found for the $\mathrm{CH}_{4}$ emissions from the three studied beds (Figure 3B). Inamori et al. (2007) reported that $\mathrm{CH}_{4}$
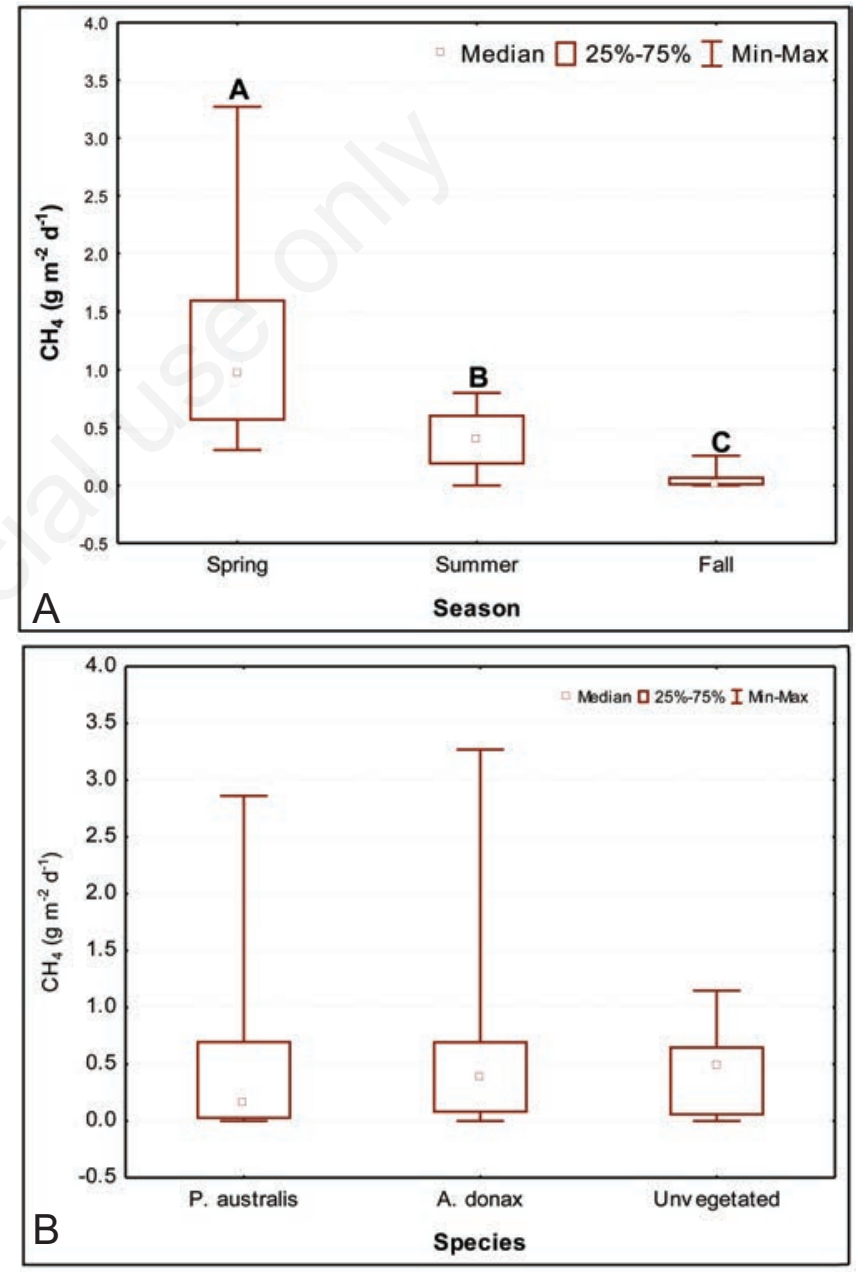

Figure 3. Emission from methane beds: A) in different seasons and $B)$ with different species.

Table 2. Above-ground and below-ground biomass production $( \pm S D)$ at the end of the study period and plant fraction incidence.

\begin{tabular}{|c|c|c|c|c|c|c|c|c|}
\hline \multirow[t]{2}{*}{ Species } & \multirow{2}{*}{$\begin{array}{l}\text { Above-ground } \\
\text { biomass } \\
\left(\mathrm{Mg} \mathrm{ha}^{-1}\right)\end{array}$} & \multicolumn{5}{|c|}{ Below-ground biomass $\left(\mathrm{Mg} \mathrm{ha}^{-1}\right)$} & \multirow{2}{*}{$\begin{array}{c}\text { Roots: Rhizomes } \\
\text { ratio }\end{array}$} & \multirow{2}{*}{$\begin{array}{c}\text { Above-ground } \\
\text { Below-ground } \\
\text { ratio }\end{array}$} \\
\hline & & $\begin{array}{l}\text { Roots } \\
0-20 \mathrm{~cm}\end{array}$ & $\begin{array}{l}\text { Roots } \\
20-40 \mathrm{~cm}\end{array}$ & $\begin{array}{l}\text { Roots } \\
40-60 \mathrm{~cm}\end{array}$ & $\begin{array}{c}\text { Rhizomes } \\
0-20 \mathrm{~cm}\end{array}$ & $\begin{array}{l}\text { Rhizomes } \\
20-40 \mathrm{~cm}\end{array}$ & & \\
\hline P. australis & $55.0 \pm 3.9$ & $0.24 \pm 0.01$ & $0.78 \pm 0.06$ & $0.12 \pm 0.02$ & $12.89 \pm 0.62$ & $6.02 \pm 0.34$ & 0.06 & 2.7 \\
\hline A. donax & $99.3 \pm 6.9$ & $3.25 \pm 0.16$ & $2.01 \pm 0.13$ & $0.57 \pm 0.08$ & $62.40 \pm 3.63$ & - & 0.09 & 1.5 \\
\hline
\end{tabular}


emission from plant units is the net balance between $\mathrm{CH}_{4}$ production by methanogens and oxidation to $\mathrm{CO}_{2}$ by methanotrophs. Given that macrophytes' aerenchymatous tissues transport and release oxygen into the rhizosphere, they increase $\mathrm{CH}_{4}$ oxidation in the anaerobic bed layers (Griess et al., 1990; Jespersen et al., 1998; McDonald et al., 2002).

Cumulative estimated $\mathrm{CH}_{4}$ emission during the study period was $159.5,134.1$ and $114.7 \mathrm{~g} \mathrm{~m}^{-2}$ for A. donax, P. australis and the unvegetated bed respectively.

The higher bed respiration and methane emissions from vegetated beds can be also attributed to more labile carbon being accessible via plant exudates (Zemanovà et al., 2010), estimated as $20 \%$ of the aboveground biomass produced during the growing season (Picek et al., 2007), that intensified bacterial activity (Gagnon et al., 2007). Ström et al. (2003) reported that $\mathrm{CH}_{4}$ emission rates and potential $\mathrm{CH}_{4}$ production are dependent on substrate quality and the linkage between root exudation of labile carbon, e.g. acetate and $\mathrm{CH}_{4}$ formation.

\section{Growing season $\mathrm{CO}_{2(\text { eq })}$ balance}

The highest monthly average daily $\mathrm{CO}_{2(\mathrm{eq})}$ emission was calculated for all beds in June and ranged from $25.9 \mathrm{~g} \mathrm{~m}^{-2} \mathrm{~d}^{-1}$ (unvegetated bed) to $60.7 \mathrm{~g} \mathrm{~m}^{-2} \mathrm{~d}^{-1}$ (bed vegetated with $A$. donax). At the end of the trial period, the two vegetated beds had similar $\mathrm{CO}_{2(\mathrm{eq})}$ cumulative emission values and trends (Figure 4) with 7.34 and $8.07 \mathrm{~kg} \mathrm{CO}_{2(\mathrm{eq})} \mathrm{m}^{-2}$ for common and giant reed respectively. The unvegetated bed instead had a cumulative $\mathrm{CO}_{2(\mathrm{eq})}$ emission of $3.81 \mathrm{~kg} \mathrm{~m}^{-2}$.

Considering the plant biomass $\mathrm{C}$ content (Table 3 ) and the beds biomass yield (Table 2), P. australis and A. donax fixed 11.61 and $27.03 \mathrm{~kg}$ $\mathrm{CO}_{2(\mathrm{eq})} \mathrm{m}^{-2}$ respectively, showing a positive balance, while the unvegetated bed, as expected, had a negative balance (Table 4).

Since CWs are multiyear wastewater depuration systems, where, after the settlement phase, $\mathrm{C}$ fixed in the plants below-ground biomass remains stable due to the root systems turnover, we can exclude it (Table 4, column 3) from the $\mathrm{CO}_{2(\mathrm{eq})}$ balance. Moreover assuming a yearly above-ground biomass cut agronomy management, the $\mathrm{CO}_{2 \text { (eq) }}$ balance for the two vegetated beds showed that during the trial period (about 9 months) they acted as $\mathrm{CO}_{2(\mathrm{eq})}$ sinks, with an atmosphere $\mathrm{CO}_{2 \text { (eq) }}$ uptake equal to 1.30 and $8.35 \mathrm{~kg} \mathrm{~m}^{-2}$ for $P$. australis and A. donax respectively (Table 4). The above-ground biomass could be used to produce renewable energy, in fact estimating the higher heating values (HHV) using $\mathrm{C}$ fixed in the biomass, in accordance with Demirba (1997) formula $\mathrm{HHV}=0.196 * \% \mathrm{C}+14.119$, A. donax and $P$. australis have an HHV respectively of 22.96 and $22.51 \mathrm{MJ} \mathrm{kg}^{-1}$.
The C3 plants studied in the Mediterranean environment determined a positive $\mathrm{CO}_{2(\mathrm{eq})}$ balance. A. donax that has a high photosynthetic rate and productivity similar to those of $\mathrm{C} 4$ species (Christou et al., 2001) fixes more than six times $\mathrm{CO}_{2(\mathrm{eq})}$ in its above-ground biomass than $P$. australis. Considering that the depuration efficiency, in terms of wastewater pollutant abatement, is not significantly different between the two plant species (Idris et al., 2012a), A. donax could be used in CW in the Mediterranean environment. Nevertheless, A. donax is a perennial plant that produces a high quantity of rhizomes concentrated in the bed first layer and could lead after several years of operation to a possible decrease of its efficiency and/or an increase in maintenance costs. Although the result showed interesting prospects for $A$. donax, so far only a few studies have been carried out on this plant and in small experimental CW beds (Calheiros et al., 2010, 2012; Idris et al., 2012a, 2012b); therefore long terms study are needed to validate the effects of this species on CW depuration efficiency and GHG emission prior to disseminate information for technology transfer.

\section{Conclusions}

CWs are natural-like systems widely used to treat different wastewaters, where depuration processes determine greenhouse gas emis-

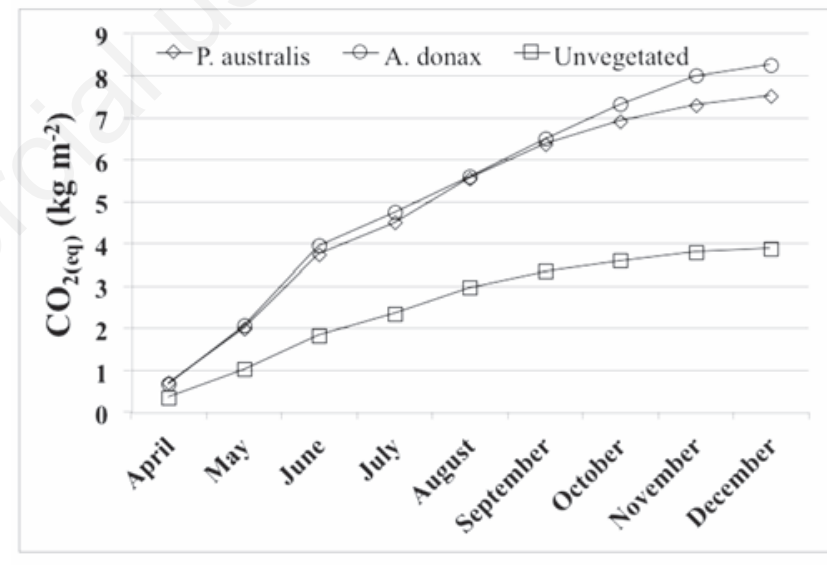

Figure 4. Cumulative $\mathrm{CO}_{2(\mathrm{eq})}$ emission trends for the three beds.

Table 3. Percentage carbon content in biomass fractions.

$\begin{array}{lccccc}\text { Species } & \begin{array}{c}\text { Above-ground biomass } \\ \text { (\%carbon) }\end{array} & \begin{array}{c}\text { Roots } \\ 0-20 \mathrm{~cm}\end{array} & \begin{array}{c}\text { Below-ground biomass (\%carbon) } \\ \text { Roots } \\ 20-60 \mathrm{~cm}\end{array} & \begin{array}{c}\text { Rhivomes } \\ 0-20 \mathrm{~cm}\end{array} & \begin{array}{c}\text { Rhizomes } \\ 20-40 \mathrm{~cm}\end{array} \\ \text { P. australis } & 42.83 & 34.31 & 38.53 & 41.06 & 39.33 \\ \text { A. donax } & 45.09 & 35.89 & 40.47 & 42.81 & -\end{array}$

Table 4. Beds $\mathrm{CO}_{2(\mathrm{eq})}$ balance $\left(\mathrm{kg} \mathrm{m}^{-2}\right)$.

\begin{tabular}{|c|c|c|c|c|c|}
\hline Species & $\begin{array}{l}\mathrm{CO}_{2(\mathrm{eq})} \\
\text { emitted }\end{array}$ & $\begin{array}{l}\mathrm{CO}_{2(\mathrm{eq})} \text { fixed } \\
\text { total biomass }\end{array}$ & $\begin{array}{c}\mathrm{CO}_{2(\mathrm{eq})} \text { fixed } \\
\text { above-ground biomass }\end{array}$ & $\begin{array}{l}\mathrm{CO}_{2(\mathrm{eq})} \\
\text { total balance* }\end{array}$ & $\begin{array}{l}\mathrm{CO}_{2(\mathrm{eq})} \text { partial } \\
\text { balance }^{\circ}\end{array}$ \\
\hline P. australis & 7.34 & 11.61 & 8.64 & 4.27 & 1.30 \\
\hline A. donax & 8.07 & 27.03 & 16.42 & 18.96 & 8.35 \\
\hline Unvegetated & 3.81 & - & - & -3.81 & -3.81 \\
\hline
\end{tabular}


sion. With this in mind Søvik et al. (2006) reported that the question then arises if CWs, used to protect freshwater ecosystems, are a solution to an environmental problem or if they substitute one problem with another by reducing water pollution, yet increasing greenhouse gas emissions.

The results achieved in this study confirm the role of plants in $\mathrm{CO}_{2}$ and $\mathrm{CH}_{4}$ emissions from $\mathrm{CWs}$ that with respect to $\mathrm{CO}_{2}$ determine significantly higher emission from vegetated beds than unvegetated ones.

Nevertheless the $\mathrm{CO}_{2(\mathrm{eq})}$ balance needs to be considered in order to have a more complete view to answer the question posed by Søvik et al. (2006). Both vegetated beds showed a positive balance $\left(\mathrm{CO}_{2}\right.$ sink), whereas the unvegetated one gave a negative value $\left(\mathrm{CO}_{2}\right.$ source $)$ confirming that vegetation in CWs contributes to enhance the environmental value of this system of wastewater depuration.

Although A. donax fixed in the above-ground biomass 1.9 more times $\mathrm{CO}_{2(\mathrm{eq})}$ than $P$. australis, it had a positive balance of $\mathrm{CO}_{2(\mathrm{eq})} 6.4$ times greater than $P$. australis. These positive preliminary results should encourage further studies to confirm the $A$. donax promising role as vegetation in Mediterranean CWs.

\section{References}

Barbera AC, Borin M, Cirelli GL, Toscano A, Maucieri C, 2014a. Carbon balance in Mediterranean pilot constructed wetlands vegetated with different C4 plant species. Environ. Sci. Pollut. R. [In press].

Barbera AC, Borin M, Ioppolo A, Cirelli GL, Maucieri C, 2014b. Carbon dioxide emissions from horizontal sub-surface constructed wetlands in the Mediterranean Basin. Ecol. Eng. 64:57-61.

Barbera AC, Cirelli GL, Cavallaro V, Di Silvestro I, Pacifici P, Castiglione V, Toscano A, Milani M, 2009. Growth and biomass production of different plant species in two different constructed wetland systems in Sicily. Desalination 246:129-36.

Borin M, Barbera AC, Milani M, Molari G, Zimbone SM, Toscano A, 2013b. Biomass production and $\mathrm{N}$ balance of giant reed (Arundo donax L.) under high water and $\mathrm{N}$ input in Mediterranean environments. Eur. J. Agron. 51:117-9.

Borin M, Politeo M, De Stefani G, 2013a. Performance of a hybrid constructed wetland treating piggery wastewater. Ecol. Eng. 51:229-36.

Borin M, Tocchetto D, 2007. Five year water and nitrogen balance for a constructed surface flow wetland treating agricultural drainage waters. Sci. Total Envir. 380:38-47.

Brix H, Sorrell BK, Lorenzen B, 2001. Are Phragmites-dominated wetlands a net source or net sink of greenhouse gases? Aquat. Bot. 69:313-24.

Bulc TG, 2006. Long-term performance of a constructed wetland for landfill leachate treatment. Ecol. Eng. 26:365-74.

Bulc TG, Ojstršek A, 2008. The use of constructed wetland for dye-rich textile wastewater treatment. J. Hazard. Mater. 155:76-82.

Calheiros CS, Quitério PV, Silva G, Crispim LF, Brix H, Moura SC, Castro PM, 2012. Use of constructed wetland systems with Arundo and Sarcocornia for polishing high salinity tannery wastewater. J. Environ. Manage. 95:66-71.

Calheiros CSC, Teixeira A, Pires C, Franco AR, Duque AF, Crispim LFC, Duque AF, Crispim LFC, Castro PML 2010. Bacterial community dynamics in horizontal flow constructed wetlands with different plants for high salinity industrial wastewater polishing. Water Res. 44:5032-8.

Christou M, Mardikis M, Kyritsis S, Cosentino S, Jodice R, Vecchiet M, Gosse G, 2001. Screening of Arundo donax L. populations in South Europe. Proc 1st World Conference on Biomass for Energy and Industry, Seville, Spain, 5-9 June 2001, pp 2048-51.
Cook CDK, 1990. Aquatic plant book. SPB Academic Publishing, The Hague, The Netherlands.

Demirba A, 1997. Calculation of higher heating values of biomass fuels. Fuel 76:431-4.

Engloner AI, 2009. Structure, growth dynamics and biomass of reed (Phragmites australis) - A review. Flora 204:331-46.

Gagnon V, Chazarenc F, Comeau Y, Brisson J, 2007. Influence of macrophyte species on microbial density and activity in constructed wetlands. Water Sci. Technol. 56:249-54.

García J, Capel V, Castro A, Ruiz I, Soto M, 2007. Anaerobic biodegradation tests and gas emissions from subsurface flow constructed wetlands. Bioresource Technol. 98:3044-52.

Grayston SJ, Vaughan D, Jones D, 1997. Rhizosphere carbon flow in trees, in comparison with annual plants: the importance of root exudation and its impact on microbial activity and nutrient availability. Appl. Soil Ecol. 5:29-56.

Gries C, Kappen L, Lösch R, 1990. Mechanism of flood tolerance in reed, Phragmites australis (Cav.) Trin. ex Steudel. New Phytologist 114:589-93.

Idris SM, Jones PL, Salzman SA, Croatto G, Allinson G, 2012a. Evaluation of the giant reed (Arundo donax) in horizontal subsurface flow wetlands for the treatment of recirculating aquaculture system effluent. Environ. Sci. Pollut. R. 19:1159-70.

Idris SM, Jones PL, Salzman SA, Croatto G, Allinson G, 2012b. Evaluation of the giant reed (Arundo donax) in horizontal subsurface flow wetlands for the treatment of dairy processing factory wastewater. Environ. Sci. Pollut. R. 19:3525-37.

Inamori R, Gui P, Dass P, Matsumura M, Xu KQ, Kondo T, Ebie Y, Inamori $\mathrm{Y}, 2007$. Investigating $\mathrm{CH}_{4}$ and $\mathrm{N}_{2} \mathrm{O}$ emissions from ecoengineering wastewater treatment processes using constructed wetland microcosms. Process Biochem. 42:363-73.

Jensen LS, Mueller T, Tate KR, Ross DJ, Magid J, Nielsen NE, 1996. Soil surface $\mathrm{CO}_{2}$ flux as an index of soil respiration in situ: A comparison of two chamber methods. Soil Biology Biochem. 28:1297-306.

Jespersen DN, Sorrell BK, Brix H, 1998. Growth and root oxygen release by Typha latifolia and its effects on sediment methanogenesis. Aquat. Bot. 61:165-80.

Johansson AE, Gustavsson AM, Oquist MG, Svensson BH, 2004. Methane emissions from a constructed wetland treating wastewater - seasonal and spatial distribution and dependence on edaphic factors. Water Res. 38:3960-70.

IPCC, 2007. Climate Change 2007: The Scientific Basis. Contribution of Working Group I to the Fourth Assessment Report of the Intergovernmental Panel on Climate Change, edited by S. Solomon et al., Cambridge Univ. Press, New York, NY, USA.

Lai W, Wang S, Peng C, Chen Z, 2011. Root features related to plant growth and nutrient removal of 35 wetland plants. Water Res. 45:3941-50.

Maltais-Landry G, Maranger R, Brisson J, Chazarenc F, 2009. Greenhouse gas production and efficiency of planted and artificially aerated constructed wetlands. Environ. Pollut. 157:748-54.

Mander Ü, Löhmus K, Teiter S, Mauring T, Nurk K, Augustin J, 2008. Gaseous fluxes in the nitrogen and carbon budgets of subsurface flow constructed wetlands. Sci. Total Environ. 404:343-53.

McDonald MP, Galwey NW, Colmer TD, 2002. Similarity and diversity in adventitious root anatomy as related to root aeration among a range of wetland and dryland grass species. Plant Cell Environ. 25:441-51.

Mitsch WJ, Bernal B, Nahlik AM, Mander Ü, Zhang L, Anderson CJ, Jørgensen SE, Brix H, 2013. Wetlands, carbon, and climate change. Landscape Ecol. 28:583-97.

0'Geen AT, Budd R, Gan J, Maynard JJ, Parikh SJ, Dahlgren RA, 2010. Chapter One-Mitigating nonpoint source pollution in agriculture 
with constructed and restored wetlands. Adv. Agron. 108:1-76.

Picek T, Čížková H, Dušek J, 2007. Greenhouse gas emission from a constructed wetland - Plants as important source of carbon. Ecol. Eng. 31:98-106.

Rossa B, Tuffers AV, Naidoo G, von Willert DJ, 1998. Arundo donax L. (Poaceae) - a C3 species with unusually high photosynthetic capacity. Bot. Acta 111:216-21.

Saarnio S, Wittenmayer L, Merbach W, 2004. Rhizospheric exudation of Eriophorum vaginatum L. - potential link to methanogenesis. Plant Soil 267:343-55.

Segers R, 1998. Methane production and methane consumption: a review of processes underlying wetland methane fluxes. Biogeochemistry 41:23-51.

Søvik AK, Augustin J, Heikkinen K, Huttunen JT, Necki JM, Karjalainen SM, Klove B, Liikanen A, Mander U, Puustinen M, 2006. Emission of the greenhouse gases nitrous oxide and methane from constructed wetlands in Europe. J. Environ. Qual. 35:2360-73.

Sorrell BK, Brix H, Schierup HH, Lorenzen B, 1997. Die-back of Phragmites australis: influence on the distribution and rate of sediment methanogenesis. Biogeochemistry 36:173-88.

Ström L, Ekberg A, Mastepanov M, Christensen TR, 2003. The effect of vascular plants on carbon turnover and methane emissions from a tundra wetland. Glob. Change Biol. 9:1185-92.

Ström L, Mastepanov M, Christensen TR, 2005. Species-specific effects of vascular plants on carbon turnover and methane emissions from wetlands. Biogeochemistry 75:65-82.

Ström L, Lamppa A, Christensen TR, 2007. Greenhouse gas emissions from a constructed wetland in southern Sweden. Wetl. Ecol. Manag. 15:43-50.

Tanner CC, Adams DD, Downes MT, 1997. Methane emissions from constructed wetlands treating agricultural wastewaters. J. Environ. Qual. 26:1056-62.

Toscano A, Langergraber G, Consoli S, Cirelli GL, 2009. Modelling pollutant removal in a pilot-scale two-stage subsurface flow constructed wetlands. Ecol. Eng. 35:281-9.

Vymazal J, 2010. Constructed wetlands for wastewater treatment: five decades of experience. Environ. Sci. Technol. 45:61-9.

Wang Y, Inamori R, Kong H, Xu KQ, Inamori Y, Kondo T, Zhang J, 2008. Influence of plant species and wastewater strength on constructed wetland methane emissions and associated microbial populations. Ecol. Eng. 32:22-9.

Wigand C, Stevenson JC, Cornwell JC, 1997. Effects of different submersed macrophytes on sediment biogeochemistry. Aquat. Bot. 56:233-44.

Zemanová K, Picek T, Dušek J, Edwards K, Šantrůčková H, 2010. Carbon, nitrogen and phosphorus transformations are related to age of a constructed wetland. Water Air Soil Poll. 207:39-48. 